\title{
Notes on North Sea Basin Cainozoic echinoderms, Part 2. The echinoid Temnechinus woodii (Agassiz in Agassiz \& Desor, 1846) from the Pliocene of the Netherlands : :
}

\author{
John W.M. Jagt ${ }^{1} \&$ Jan Idema ${ }^{2}$ \\ ${ }^{I}$ Natuurhistorisch Museum Maastricht, Postbus 882, NL-6200 AW Maastricht, the Netherlands \\ (mail@nhmmaastricht.nl); ${ }^{2}$ Instituut voor Taxonomische Zoölogie (Zoölogisch Museum), \\ Universiteit van Amsterdam, Postbus 94766, NL-1090 GT Amsterdam, the Netherlands
}

Keywords: Echinoidea, Temnopleuridae, Pliocene, North Sea Basin

\begin{abstract}
The Pliocene temnopleurid echinoid Temnechinus woodii (Agassiz in Agassiz \& Desor, 1846) (=T, excavatus Forbes, 1852) is recorded from the Westerschelde at Ellewoutsdijk (province of Zeeland) and from borehole IJsselmuiden-1 near Wezep (province of Overijssel). First described from the Coralline and Red crags (Pliocene-Lower Pleistocene) of southeast England, and long held to be confined to those deposits, material apparently assignable to $T$. woodii was recorded in the 1940 s and $1950 \mathrm{~s}$ from boreholes at Roosendaal and Oosterhout (province of Noord-Brabant). All Dutch records are from deposits referred to the Oosterhout Formation, which correlates with the Lillo Formation in the Antwerp area (Belgium), from where, perhaps surprisingly, $T$. woodil is still not known.
\end{abstract}

\section{Contents}

Introduction

Description

Discussion

Stratigraphy

Acknowledgements

References

\section{Introduction}

The present contribution is the second in a series of brief notes on Cainozoic echinoderms, including crinoíds (Jagt et al., 2002). A temnopleurid echinoid, Temnechinus woodii, is recorded from material (mainly molluscan) dredged from both the Westerschelde and dumped at Ellewoutsdijk, as well as recovered from borehole IJsselmuiden-1. The Ellewoutsdijk specimen is the first complete, al- beit slightly worn, test on record from Pliocene deposits in the Netherlands. Material from the IJsselmuiden-1 borehole comprises dissociated test and genital plates only, and stems from strata assigned to the Oosterhout Formation (i.e., marine Pliocene), which correlates with the Lillo Formation in the Antwerp-Kallo area of Belgium. A similar age may be assumed for the Ellewoutsdijk specimen.

Repositories of material referred to in the text are as follows: NHM The Natural History Museum, London (formerly British Museum of Natural History); NHMM Natuurhistorisch Museum Maastricht, Maastricht; UvA Universiteit van Amsterdam, Zoölogisch Museum.

\section{Description}

Family Temnopleuridae A. Agassiz, 1872

Genus Temnechinus Forbes, 1852

Type species: Lambert \& Thiéry (1911, p. 233) considered T. excavatus Forbes, 1852 to be the type, as did Mortensen (1943). As shown below, this is a junior synonym of $T$. woodii.

Temnechinus woodii (Agassiz in Agassiz \& Desor, 1846)

Figs. 1, 2

* 1846 Temnopleurus woodii Agassiz in L. Agassiz \& Desor, p. 360.

* 1852 Temnechinus excavatus Forbes, p. 6, pl. 1, fig. 1. 
1891 Temnechinus woodi (L. Agassiz), 1846 - Gregory, p. 30 (with additional synonymy).

1983 Temnechinus excavatus Forbes - Roman, p. 11, pl. 2, figs. 1-8 (with additional synonymy).

\section{Types}

The type specimens of $T$. excavatus (NHM E 585) and T. globosus (NHM E 583) (Forbes, 1852, pl. 1 , figs. 1 and 3, respectively) are both from the Coralline Crag of Ramsholt, Suffolk (England). The type of T. turbinatus (NHM E 584) (Forbes, 1852, pl. 3, fig. 11) is from the Red Crag of Sutton. Lewis (1986) assigned a syntype of $T$. melocactus (NHM E 590) (Forbes, 1852, pl. 1, fig. 2) to $T$. woodii, and considered $T$, turbinatus and $T$, woodii to be synonymous.

When erecting $T$, woodii, Agassiz in Agassiz \& Desor (1846) did not specifically refer to the S.V. Wood Collection, now at The Natural History Museum (London), although the species obviously is named after him. Nor did he indicate the number of specimens available to him. It could well be that Agassiz based his brief description on (a) specimen(s) in his own collection, either presented to him by someone else, or perhaps collected by himself. If found, this specimen, or one of these specimens, should be designated lectotype.

\section{Description}

Although details of test sculpture and ambulacral plating in UvA V.Ech. E8924, from Ellewoutsdijk, cannot be fully assessed due to post-mortem abrasion, the specimen does show the following characters:

Medium-sized test (diameter $19.2 \mathrm{~mm}$ ), outline more or less circular, but slightly depressed interradially, adradially and, although less markedly, perradially. Test height $49 \%$ of test diameter; in profile, ambitus is at mid-height, smoothly rounded below and slightly more conical above.

Apical disc (missing) of medium size, occupying $35 \%$ of test diameter, and faintly sunken; margin slightly indented, mostly interradially.

Ambulacra straight, tapering adapically; width at ambitus c. $27 \%$ of test diameter. Pore pairs arranged in distinct oblique arcs of three. Each ambulacral plate with single large, imperforate noncrenulate primary tubercle, close to adradial margin, occupying more than $50 \%$ of plate height; perradial zone comparatively wide, with smaller tubercles/granules and angular pits; 12-13 ambulacral tubercles in a column.

Interambulacra straight; width at ambitus c. $36 \%$ of test diameter; 9-10 tubercles in a column. Interambulacral plates considerably wider than tall, with single, large (albeit smaller than ambulacral one) imperforate, noncrenulate primary tubercle, situated closer to adradial than to perradial suture; perradial zone comparatively wide with fairly dense cover of smaller tubercles and granules, and deep subcircular to elongate angular pits. Adapical perradial zones in all interambulacra conspicuously wide and deeply sunken.

Peristome slightly sunken; buccal notches small but clearly incised; diameter c. $33 \%$ of test diameter.

Material (NHMM 2001 085-087) from the IJsselmuiden-1 borehole (Fig. 3; co-ordinates: $\mathrm{x}-$ 194.627.15; $y-500.411 .22$ ), from depths between 257-266 and 277-281 m, comprises dissociated ambulacral/interambulacral and genital plates only. Numerous spines in the same samples compare well to material illustrated and briefly discussed by Forbes (1852), and Mortensen (1943) and may belong to $T$. woodii as well. A handful of stout genital plates, with a raised, coarsely tuberculate/ granulate upper portion, and smooth sloping distal part, with the genital opening at the very edge, correspond closely to illustrations in Roman (1983, pl. 2, figs. $3,4,7,8$ ).

\section{Discussion}

Although worn, test features of the Ellewoutsdijk specimen (Figs. 1,2) are such that assignment to T. woodii is beyond doubt. In fact, it is closely comparable to a syntype of $T$. excavatus (NHM E 12729), from the Coralline Crag of Sutton (Suf- 
folk), illustrated by Roman (1983, pl. 2, figs. 1, 2).

Originally, Forbes (1852, pp. 6-9) assigned the following species to the newly erected genus Temnechinus:

1 - from the Coralline Crag at Ramsholt:

T. excavatus Forbes, 1852 (p. 6, pl. 1, fig. 1);

T. melocactus Forbes, 1852 (p. 7, pl. 1, fig. 2);

T. globosus Forbes, 1852 (p. 8, pl. 1, fig. 3).

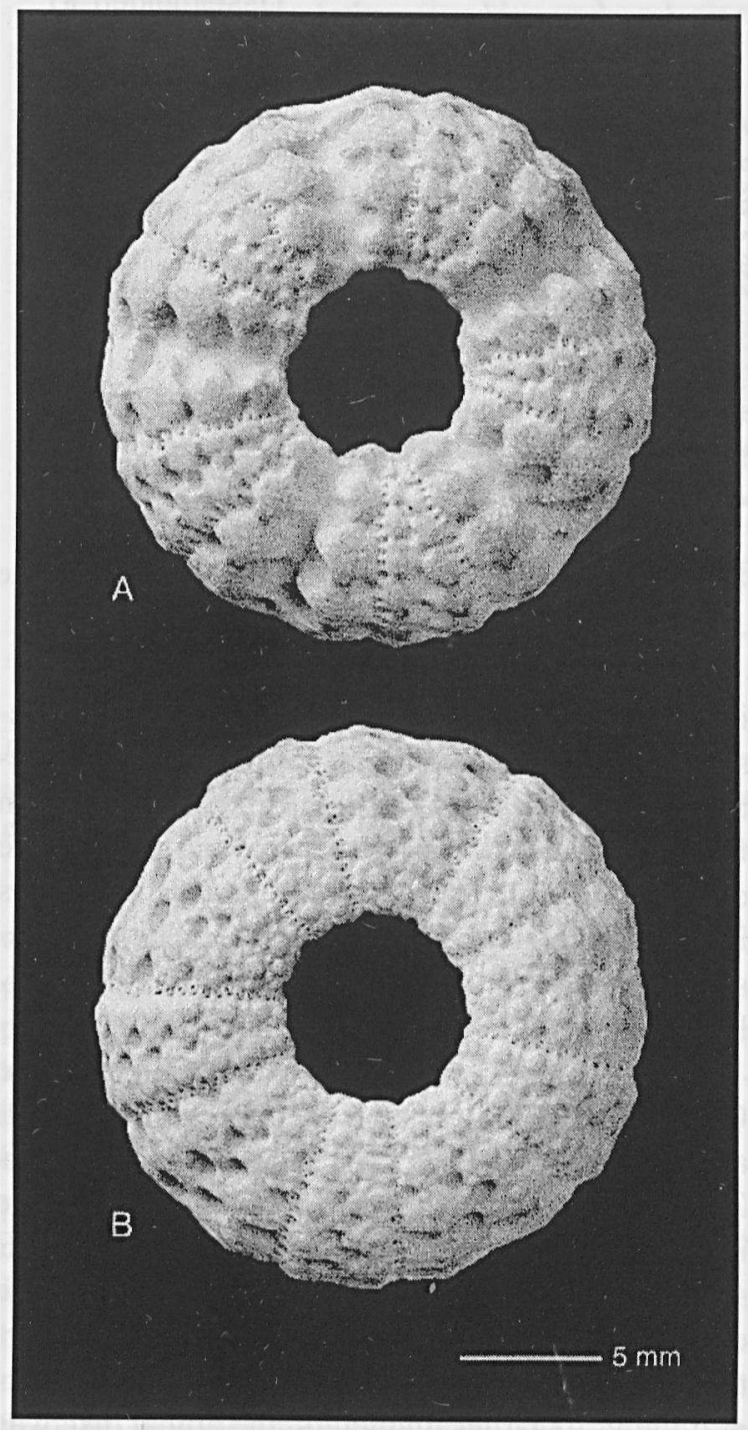

Fig. 1. Temnechinus woodii (Agassiz in Agassiz \& Desor, 1846), UvA V.Ech. E8924, dredged from Westerschelde at Ellewoutsdijk, province of Zeeland (the Netherlands), from strata of * Pliocene age, correlatable with the Oosterhout Formation in the Netherlands and with the Coralline Crag of Suffolk (southeast England): A - apical view; B - oral view.

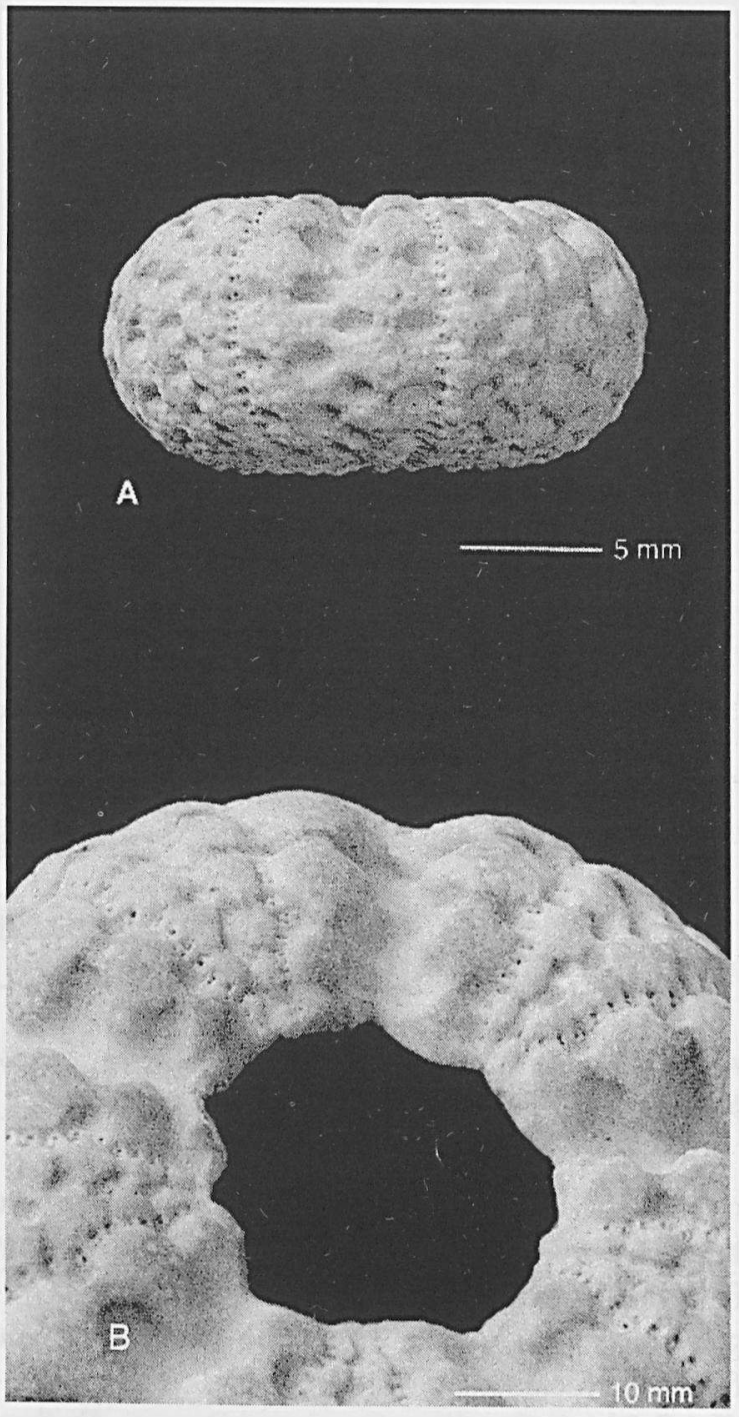

Fig. 2. Temnechinus woodii (Agassiz in Agassiz \& Desor, 1846), UvA V.Ech. E8924, data as in Fig. 1: A - lateral view; B oblique apical view to show conspicuous adapical perradial depressions in interambulacra.

2 - from the Red Crag at Sutton:

T. turbinatus Forbes, 1852 (p. 8, pl. 3, fig. 11).

Apparently, Desor (1856, pp. 106, 107) accepted Forbes's arguments concerning the specific status of these forms, but with $T$. melocactus he did note that, 'Reste à savoir si les différences [...] indiquées par M. Forbes, ne sont pas de simples différences d'âge.'

In a subsequent revision, Gregory (1891) came to the conclusion that $T$. excavatus, $T$. melocactus and $T$. turbinatus were conspecific and should be 


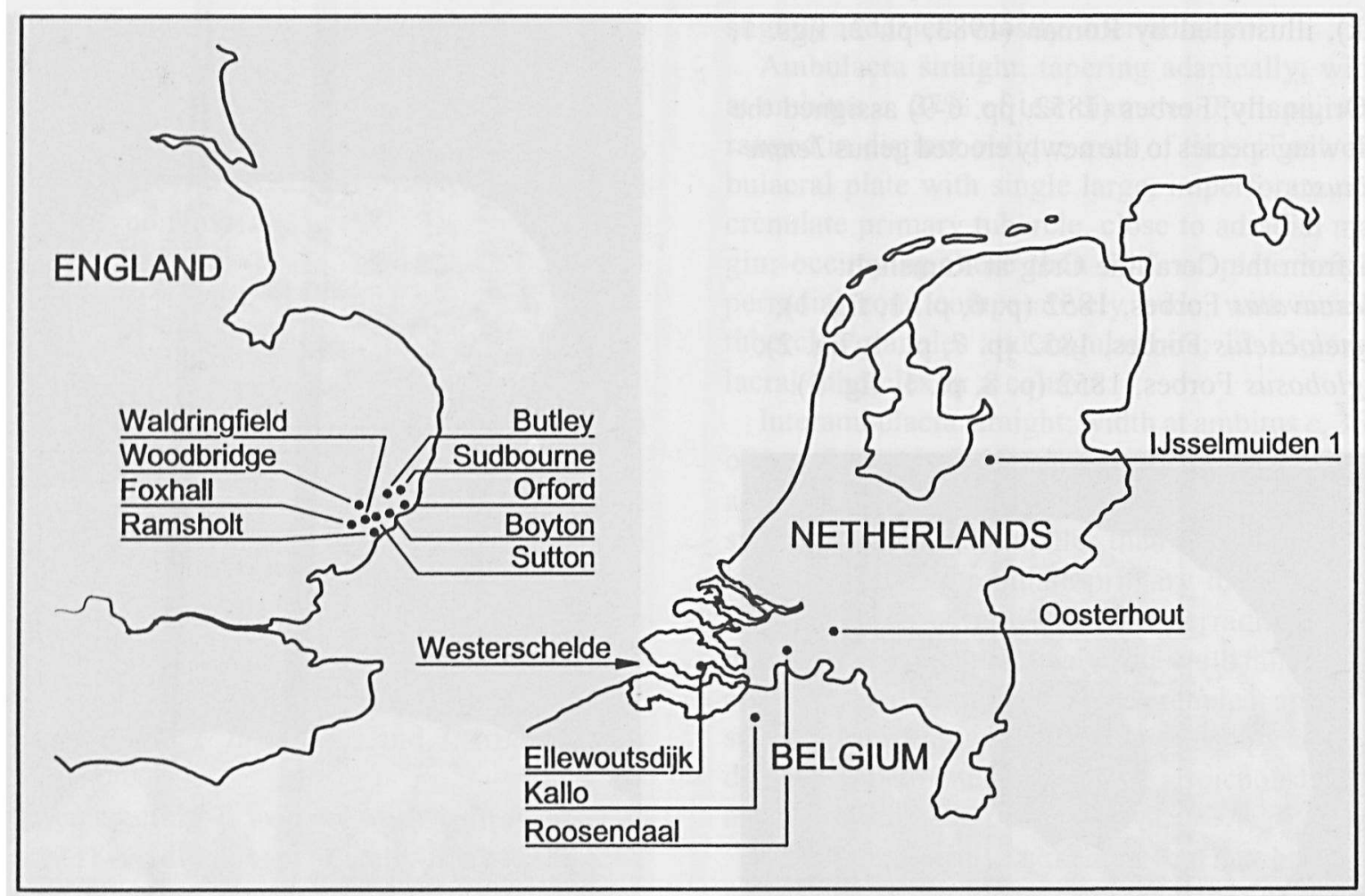

Fig. 3. Localities in SE England and the Netherlands from which Temnechinus woodii has so far been described, inclusive of the present records. The Antwerp-Kallo area is also shown.

named $T$. woodi, since that name had priority (see below). Of $T$. globosus, Gregory (p. 32) noted that it, '... is probably distinct'. Material seen by Gregory (1891) all came from crag deposits at the following localities: Orford, Ramsholt, Sutton, Waldingfield (all Coralline Crag) and Boyton, Butley, Foxhall, Sudbourne, Sutton, Waldingfield and Woodbridge (all Red Crag) (Fig. 3). Gregory (1891) also commented in detail on the occurrence of socalled 'marsupial pouches' in these echinoids, and considered $T$. excavatus to represent the female morphotype and T. melocactus the male.

With regard to Gregory's adoption of the name T. woodii, Mortensen (1943, p. 276) noted that the name Temnopleurus excavatus was first used by Morris (1843, p. 60) in a list and was thus, strictly speaking, a nomen nudum. He went on to say that, '... I think Forbes, who no doubt knew the type specimen(s), was entitled to take it up; and the name excavatus is so appropriate that it is certainly desirable to keep it.' We do not subscribe to this view. Instead, we follow Gregory (1891) and Lewis (1986) in accepting $T$. woodii, since the diagnosis of Agassiz (in Agassiz \& Desor, 1846, p. 360), 'Très petite espèce remarquable par le prolongement en forme de mufle de l'appareil anal qui est entouré d'une étoile, dont les rayons empiètent sur les aires interambulacraires. Du crag d'Angleterre. - Agassiz', seems perfectly acceptable, although no illustration was provided.

Roman (1983), who studied material from the Coralline Crag of Ramsholt (NHM E 12728-12730) and of Sutton (NHM E 41904-41913), listed as Temnechinus excavatus, noted that the apical disc in a small-sized specimen from Sutton (NHM E 41912) was reminiscent of that in females of the extant temnopleurid Hypsiechinus coronatus Mortensen, 1903 in being raised above the test in lateral view. At larger diameters, the apical disc was more or less flush with the test (compare Roman, 1983, pl. 2, figs. 3, 4 and 7, 8, respectively). Roman (1983) also drew attention to the wide range of variation in interambulacral depressions and commented on their interpretation as marsupia, 


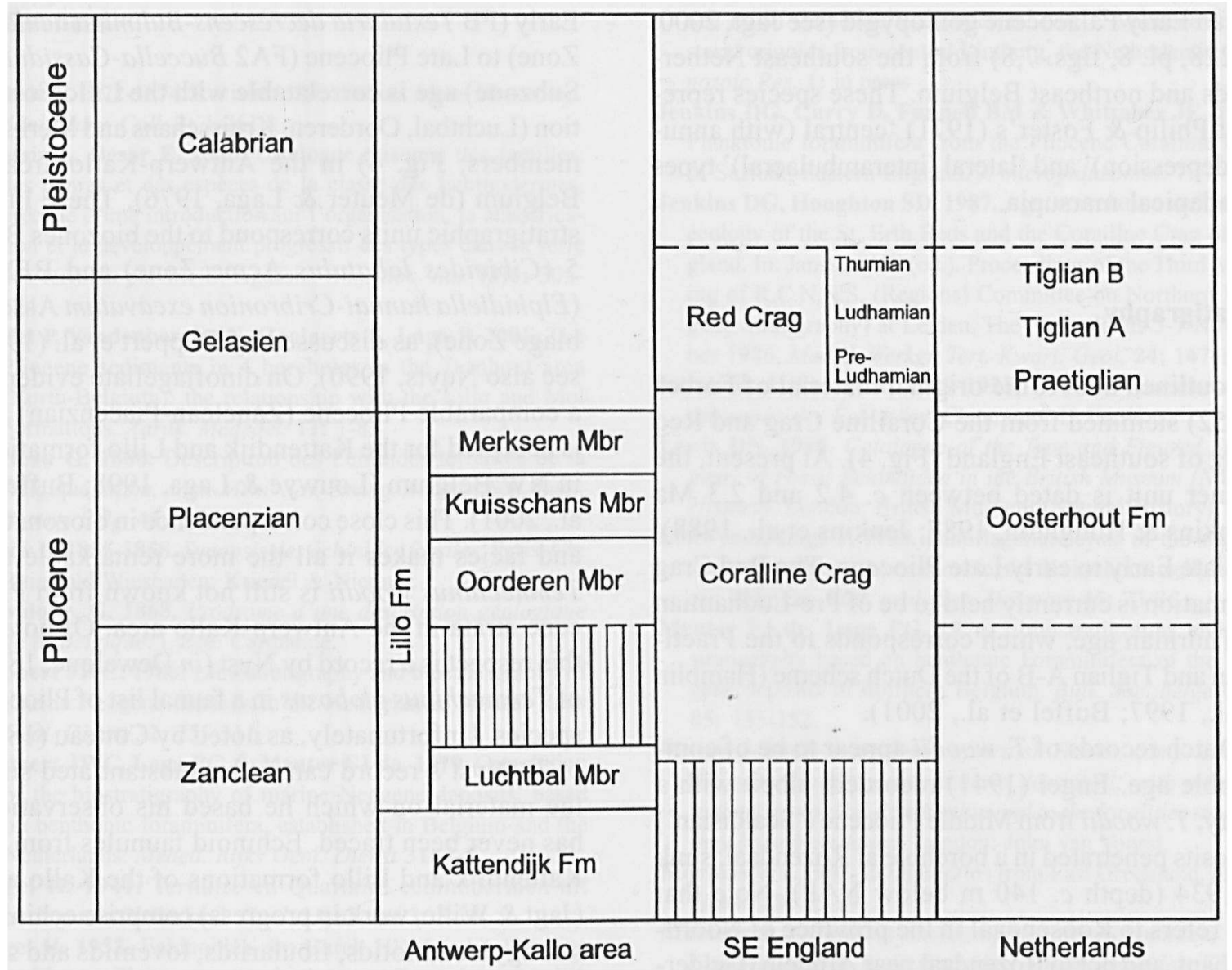

Fig. 4. Comparison of lithostratigraphy of Pliocene and Lower Pleistocene strata in SE England, the Antwerp-Kallo area (Belgium) and the Netherlands, using data provided mainly by Doppert et al. (1979), Hamblin et al. (1997), Louwye \& Laga (1998) and Buffel et al. (2001).

noting a general similarity of such features in $T$. excavatus to those in other temnopleurids and goniopygids. Philip \& Foster (1971, pp. 667, 668), upon a re-examination of material in the NHM collections and those of the Sedgwick Museum (Cambridge), had earlier concluded that, '... no dimorphism exists in these last two species', these species being Temnechinus excavatus and 'Echinus' henslovi Forbes, 1852. We are undecided on the basis of our own material. Although certain specimens (e.g., Roman, 1983, pl. 2, figs. 3, 4) appear to have well-delimited pouches, they cannot be readily assigned to any of the categories of adapical marsupia distinguished by Philip \& Foster (1971). Moreover, there is no clear distinction between specimens of $T$. woodii with interambulacral depressions, of variable depth and width, and those without. Those without could be expected to represent males of a sexually dimorphic species, but since these have not been recorded yet the interpretation of $T$. woodii as a marsupiate echinoid would seem to lack substantiation. In view of the fact that the crag deposits in southeast England are quite popular with (local) fossil collectors, it may be that additional material of $T$. woodii has been collected in recent years. Stratigraphically welldocumented 'populations', preferably representing various growth stages, are needed to settle this matter.

Widely accepted sexual dimorphism has previously been demonstrated for the Late CretaceousEarly Palaeocene temnopleurids Thylechinus vanderhami Smith \& Jeffery, 2000 and Micropsidia? sp. (see Jagt, 2000, p. 245, pl. 14, figs. 1-4), and 
for an Early Palaeocene goniopygid (see Jagt, 2000, p. 228, pl. 8, figs. 7,8) from the southeast Netherlands and northeast Belgium. These species represent Philip \& Foster's (1971) 'central (with annular depression)' and 'lateral (interambulacral)' types of adapical marsupia.

\section{Stratigraphy}

As outlined above, the original material of Forbes (1852) stemmed from the Coralline Crag and Red Crag of southeast England (Fig. 4). At present, the former unit is dated between c. 4.2 and $2.3 \mathrm{Ma}$ (Jenkins \& Houghton, 1987; Jenkins et al., 1988), i.e. late Early to early Late Pliocene. The Red Crag Formation is currently held to be of Pre-Ludhamian to Thurnian age, which corresponds to the Praetiglian and Tiglian A-B of the Dutch scheme (Hamblin et al., 1997; Buffel et al., 2001).

Dutch records of $T$. woodii appear to be of comparable age. Engel (1941) recorded, albeit with a query, $T$, woodii from Middle Pliocene ('Scaldisian') deposits penetrated in a borehole at Rozendaal, sunk in 1934 (depth c. $140 \mathrm{~m}$ below NAP). Note that this refers to Roosendaal in the province of NoordBrabant, and not to Rozendaal near Arnhem (Gelderland). Engel (1953, p. 36, fig. 2) listed poorly preserved test fragments from borehole 604/202 (sunk in 1949), at the site of the waterworks near Oosterhout (Noord-Brabant), at depths between 162-173.5 and $180-183 \mathrm{~m}$, which he considered might be assignable to Temnechinus turbinatus. Interestingly, he noted differences between this material and the specimen he illustrated in his 1941 paper, and pointed out that Mortensen, whom he had sent his material, was of the opinion that $T$. turbinatus was not conspecific with $T$. woodii (=T. excavatus), contrary to Gregory (1891). Interambulacral angular pits appear less deep and much smaller (Engel, 1953, fig. 2), and ambulacral pore pairs are much more oblique than in the present specimen (see Figs. $1,2)$. However, for the time being, this material is considered to fall within the range of $T$. woodii. The IJsselmuiden-1 material from the interval between 189 and c. $330 \mathrm{~m}$, according to Gaemers (1986), may be assigned to the Oosterhout Formation.

The Oosterhout Formation (Doppert, 1980) of
Early (FB Textularia decrescens-Bulimina aculeata Zone) to Late Pliocene (FA2 Buccella-Cassidulina Subzone) age is correlatable with the Lillo Formation (Luchtbal, Oorderen, Kruisschans and Merksem members; Fig. 4) in the Antwerp-Kallo area of Belgium (de Meuter \& Laga, 1976). These lithostratigraphic units correspond to the biozones BFN 5 (Cibicides lobatulus Acme Zone) and BFN 6 (Elphidiella hannai-Cribronion excavatum Assemblage Zone), as discussed by Doppert et al. (1979; see also Nuyts, 1990). On dinoflagellate evidence, a comparable Pliocene (Zanclean-Piacenzian) age is accepted for the Kattendijk and Lillo formations in NW Belgium (Louwye \& Laga, 1998; Buffel et al., 2001). This close correspondence in biozonation and facies makes it all the more remarkable that Temnechinus woodii is still not known from Pliocene strata in the Antwerp-Kallo area. Of note in this respect is a record by Nyst (in Dewalque, 1868) of Temnechinus globosus in a faunal list of Pliocene species. Unfortunately, as noted by Cotteau (1880, p. 7), Nyst's record cannot be substantiated since the material on which he based his observations has never been traced. Echinoid faunules from the Kattendijk and Lillo formations of the Kallo area (Jagt \& Wille, work in progress) comprise echinids, strongylocentrotids, fibulariids, loveniids and spatangids, but no temnopleurids.

With other records all securely dated as Pliocene (Oosterhout Formation), a similar age assignment may be assumed for the Ellewoutsdijk specimen despite the fact that dredged material is difficult to date precisely.

\section{Acknowledgements}

We thank Dr P.A.M. Gaemers (Leiden) for inviting one of us (JWMJ) to participate in the (discontinued) IJsselmuiden-1 project, Dr Annelies C. Pierrot-Bults and Joke Bleeker (both Universiteit van Amsterdam) for allowing material to be studied and borrowed, L. van der Laan (Universiteit van Amsterdam) and $\mathrm{H}$. Bongaerts (Posterholt) for preparation of photographs and text-figures, respectively, and Drs A.B. Smith (The Natural History Museum, London), B. David (Université de Bourgogne, Dijon), and S.K. Donovan (Nationaal Natuurhistorisch Museum, Leiden) for suggesting improvements to an earlier typescript. 


\section{References}

Agassiz A. 1872-1874. Revision of the Echini. Mem. Mus. comp. Zool. Harv, Coll. 3: 1-761, *

Agassiz L, Desor E. 1846. Catalogue raìsonné des familles, des genres et des espèces de la classe des Échinodermes, précédé d'une introduction sur l'organísation, la classification et le développement progressif des types dans la série des terrains par M. L. Agassiz. Ann. Soc. nat. (3)6: 305374.

Buffel P, Vandenberghe N, Goolaerts S, Laga P. 2001. The Pliocene sediments in $\mathbf{4}$ boreholes in the Turnhout area (North-Belgium): the relationship with the Lillo and Mol Formations. Aardk. Mededel. 11: 1-8.

Cotteau G. 1880. Description des Échinides tertiaíres de la Belgique. Mếm. cour. Mếm. Sav, étrang. Acad. r. Sci., Lett.,

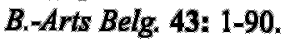

Desor E. 1855-1858. Synopsis des échinides fossiles. Paris: $\mathrm{Ch}$. Reinwald/Wiesbaden: Kriedel \& Niedner.

Dewalque, G. 1868. Prodrome d'une description géologique de la Belgique. Liège: Carmanne.

Doppert JWC. 1980. Lithostratigraphy and biostratigraphy of marine Neogene deposits in the Netherlands. Meded. Rijks Geol. Dienst 32: 255-311.

Doppert JWC, Laga PG \& Meuter FJ de. 1979. Correlation of the biostratigraphy of marine Neogene deposits, based on benthonic foraminifera, established in Belgium and the Netherlands. Meded. Rijks Geol. Dienst 31: 1-8.

Engel H. 1941. Tertiaire en Quartaire echinodermen uit boringen in Nederland. Geol. Mijnbouw 3: 5-17.

Engel H. 1953. Echinoídea. In: Burck HDM (ed.). Pliocene and Lower Pleistocene in a boring near Oosterhout, Meded. Geol. Sticht, n.s. 7: 36-37.

Forbes E. 1852. Monograph of the Echinodermata of the British Tertiaries. Monogr. Palaeontogr. Soc. Lond. 6(19): vii + $36 \mathrm{pp}$.

Gaemers PAM. 1986. Boring IJsselmuiden-1, een WTKGprojekt. Afzettingen 7: 52-56.

Gregory JW. 1891. A revision of the British fossil Cainozoic Echinoidea. Proc. Geol. Ass. 12: 16-60.

Hamblin RJO, Moorlock BSP, Booth SJ, Jeffery DH \& Morigi AN. 1997. The Red Crag and Norwich Crag formations in eastern Suffolk. Proc. Geol. Ass. 108: 11-23.

Jagt JWM. 2000. Late Cretaceous-Early Palaeogene echinoderms and the $\mathrm{K} / \mathrm{T}$ boundary in the southeast Netherlands and northeast Belgium. Part 4: Echinoids. Scripta Geol. 121: 181-375.

Jagt JWM, Deckers MJM \& Parren J. 2002. Notes on North
Sea Basin Cainozoic echinoderms, Part 1. Miocene comasterid crinoids from central Limburg, the Netherlands. Cainozoic Res. 1: in press

Jenkins DG, Curry D, Funnell BM \& Whittaker JE. 1988. Planktonic foraminifera from the Pliocene Coralline Crag of Suffolk, Eastern England. $J$, micropalaeontol. 7: 1-10.

Jenkins DG, Houghton SD. 1987. Age, correlation and paleoecology of the St. Erth Beds and the Coralline Crag of England. In: Janssen AW (ed.). Proceedings of the Third Meeting of R.C.N.N.S. (Regional Committee on Northern Neogene Stratigraphy) at Leiden, The Netherlands 5-7 November 1986. Meded. Werkgr. Tert. Kwart. Geol. 24: 147-156.

Lambert J, Thiéry P. 1909-1925. Essai de nomenclature raisonnée des Echinides. Chaumont: L. Ferrière.

Lewis DN. 1986. Catalogue of the Type and Figured Specimens of Fossil Echinoidea in the British Museum (Natural History). London: British Museum (Natural History).

Louwye S, Laga P. 1998. Dinoflagellate cysts of the shallow marine Neogene succession in the Kalmthout well, northern Belgium. Bull. geol. Soc. Denmark 45: 73-86.

Meuter FJ de, Laga PG. 1976. Lithostratigraphy and biostratigraphy based on benthonic Foraminifera of the Neogene deposits of northern Belgium. Bull. Soc. belge Géol. 85: 133-152.

Morris J. 1843. A catalogue of British Fossils, comprising all the genera and species hitherto described; with reference to their geological distribution and to the localities in which they have been found. London: John van Voorst.

Mortensen T. 1903. Echinoderms from East Greenland. Meddr Gronl. 29: 65-89.

Mortensen T. 1943. A monograph of the Echinoidea, 3(2). Camarodonta I, I. Orthopsidae, Glyphocyphidae, Temnopleuridae and Toxopneustidae. Kobenhavn: C.A. Reitzel.

Nuyts H. 1990. Note on the biostratigraphy (benthic Foraminifera) and lithostratigraphy of Pliocene deposits at Kallo (Oost-Vlaanderen; Belgium), Contr. Tert. Quatern. Geol. 27: 17-24.

Philip GM, Foster RJ. 1971. Marsupiate Tertiary echinoids from south-eastern Australia and their zoogeographic significance. Palaeontology 14: 666-695.

Roman J. 1983. Échinides "marsupiaux" (Fam. Temnopleuridae) dans le Néogène de l'ouest européen. Ann. Paléont. (Vert.-Invert.) 69: 13-42.

Smith AB, Jeffery CH. 2000. Maastrichtian and Palaeocene echinoids: a key to world faunas. Spec, Pap. Palaeont. 63: 1-406.

Received: 13 August 2001 